\title{
THE EFFECT OF NASO-PHARYNGEAL OPERATIONS ON RENAL FUNCTION
}

\author{
BY IRVINE H. PAGE AND ALF ALVING \\ (From the Hospital of the Rockefeller Institute for Medical Research, New York)
}

(Received for publication May 31, 1932)

The operations, tonsillectomy, adenoidectomy, and tooth extraction, are among the most practised therapeutic procedures in Bright's disease. Whether patients suffering from Bright's disease are able, without detriment to their kidneys, to undergo such operations, and whether the operations are likely to affect the subsequent course of the renal disease, are questions which form the object of the present analysis of results. It is based on data from the records of the nephritic clinic of the Hospital of the Rockefeller Institute collected over a period of several years.

Tonsillectomies and adenoidectomies were all performed by Dr. Stuart Craig under gas-oxygen-ether anesthesia, and extractions of teeth by Dr. Frank Wynn using procaine anesthesia. The patients were under the immediate care of Drs. MacKay, Johnston, McIntosh, Moore, Kirk, and Alving.

The cases are classified according to the modification of Volhard and Fahr's classification made by Addis, as described in a previous monograph from this hospital (8).

\section{DATA OBSERVED}

The "blood urea clearance," indicating the cubic centimeters of blood per minute cleared of urea by renal excretion, has been shown by Van Slyke, McIntosh, Möller, Hannon, and Johnston (7) to be a sensitive indicator of changes in renal function. The urea clearance tests were conducted as proposed by Möller, McIntosh and Van Slyke (2) with the patient at rest in bed. It is important to stress the latter point because Van Slyke, Alving and Rose (6) have shown that the clearance in some of the more advanced cases may be significantly reduced by allowing the patient to walk about during the two-hour period of the test. We have recorded the results in percentages of the average normal clearance.

Phenolsulphonphthalein excretion tests were also conducted at the same time as the urea clearance.

Under "duration of disease" the time is given from apparent onset until operation was performed.

Edema, blood pressure, and eye ground examination were usually recorded within a reasonably short period of operation. We have made no effort to call attention to the detail of the eye ground examination, 
and where we record negative we mean that no gross change, such as hemorrhage and edema, is present.

Hemoglobin is given in terms of oxygen capacity (20.7 volumes per cent being normal for adult men, 19.0 for women) (4).

The normal value for total plasma protein is about 7 per cent. When total protein falls below 5.2 to 5.8 per cent, or the albumin, normally averaging 4.3 per cent, falls below 2.3 to 2.7 per cent, edema is usually present (3).

The Addis sediment test gives the number of red blood cells and casts in a twelve hour specimen collected after a period of twelve hours in which the patient is on a dry diet (1). In many cases it has not been possible immediately after surgical operation to perform this test for obvious reasons. Protein in the urine is recorded for 24 hours, as determined by the sedimentation method of Shevky and Stafford (5).

\section{Histories of three cases in which renal function diminished after operation}

In the series of 31 cases there were 3 in which a marked fall in blood urea clearance followed operation. The histories of these 3 cases are given below. In one of them (No. 1), already in the terminal stage of renal disease and rapidly progressing, the urea clearance fell permanently after operation, which apparently accelerated the fatal course of the disease. In the other two patients the diminution of renal function after operation was temporary, and it does not appear that the progress of the disease was accelerated.

The first patient (No. 1) discovered that he had albuminuria and hematuria during the course of an insurance examination in June 1928. On his admission December 1928, he was edematous, had lost weight, and the blood pressure measured 166/86. Large quantities of albumin, many casts, and red blood cells were found in the urine. The course in the hospital was progressively down hill, terminating in convulsions and death. Features of interest during the course of the disease were, venous thrombosis in the popliteal fossa (December 19), marked increase in the formed elements in the urine following slight upper respiratory infection (March 15), gross hematuria resultant from a streptococcic pharyngitis (April 19), and right bundle branch block on June 9. The urea clearance on admission was 27 per cent of normal and fell progressively to 16 per cent on May 8. On May 11, tonsillectomy and adenoidectomy were performed under gas-oxygen-ether. No gross hematuria was noted after the operation. On May 23, the patient had still not recovered from the operation. He vomited frequently, and was weak, drowsy, and dehydrated. Complete suppression of urine occurred from 6 p.m. on May 23, until he was catheterized at 8 p.m. on May 26. The catheterized specimen contained no acetone or acetoacetic acid, and the specific gravity was 1.017. The plasma p.H was 7.31, $\mathrm{CO}_{2}$ content $20.58 \mathrm{mM}$. per liter and chloride $72.1 \mathrm{mM}$. per liter on May 27 . It was not until June 16, that the patient was again bright and cheerful. At that time it was found that the clearance had fallen to 2.4 per cent of normal. Death occurred in uremia on July 2 nd. 


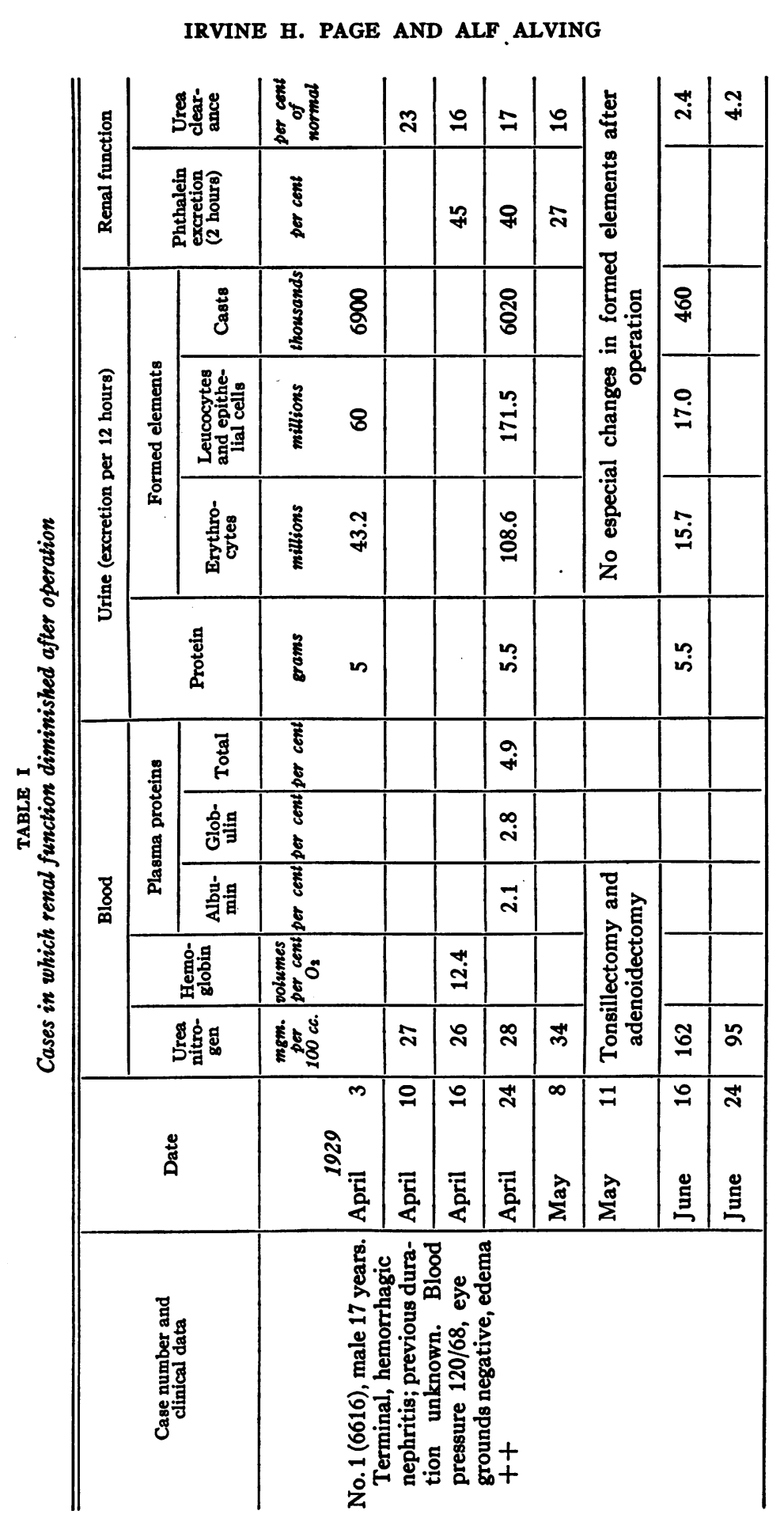




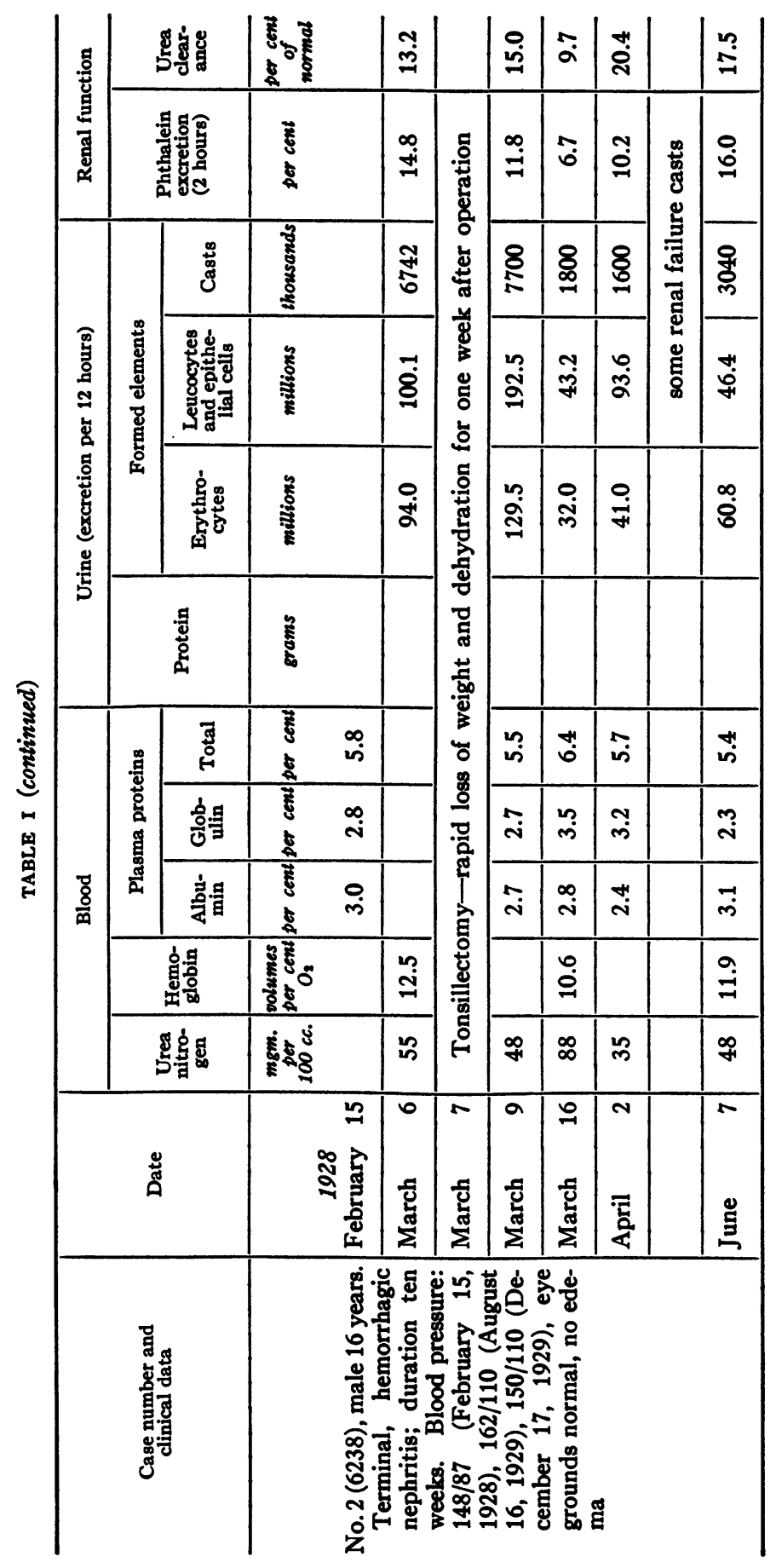


IRVINE H. PAGE AND ALF ALVING

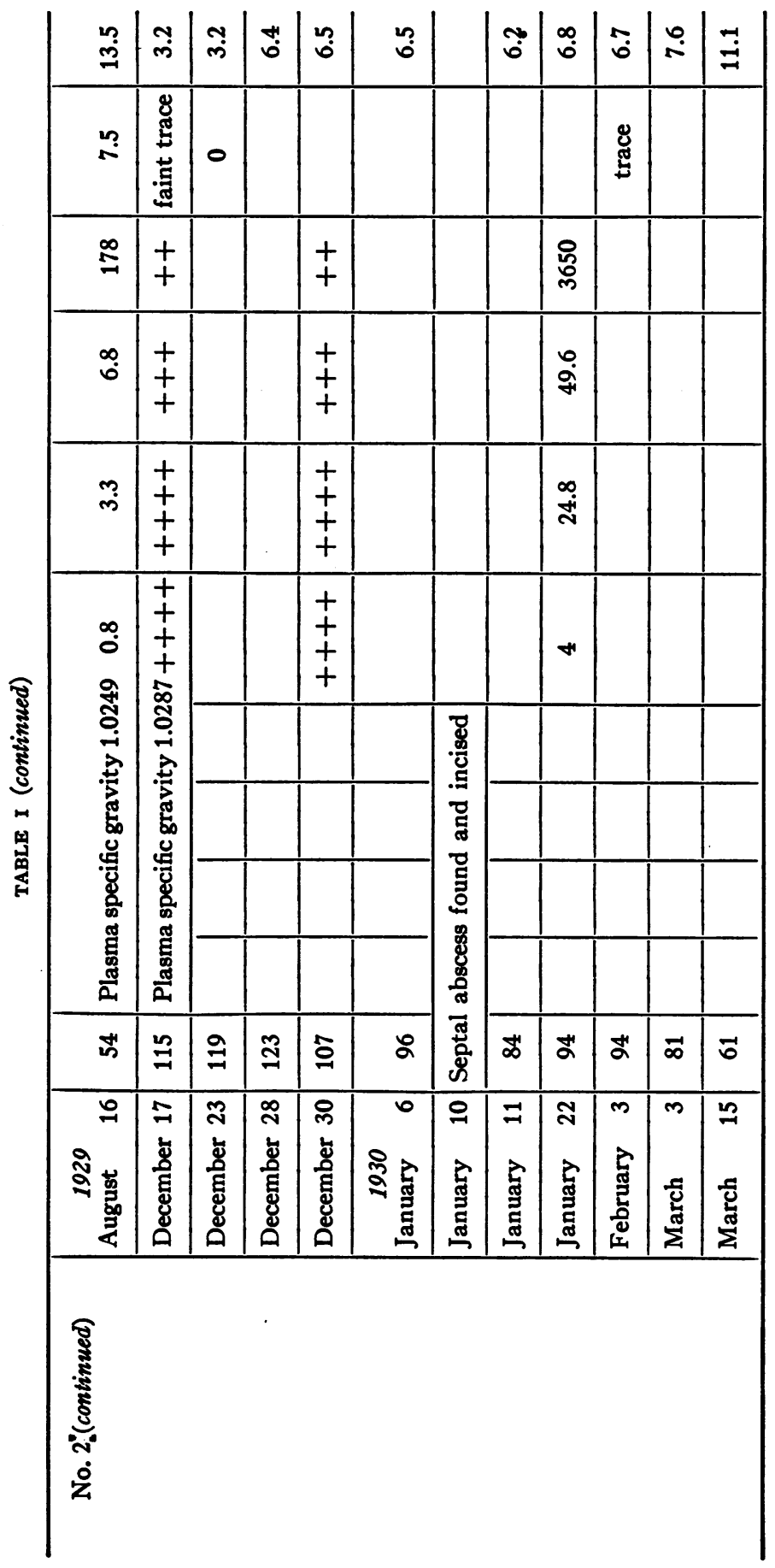




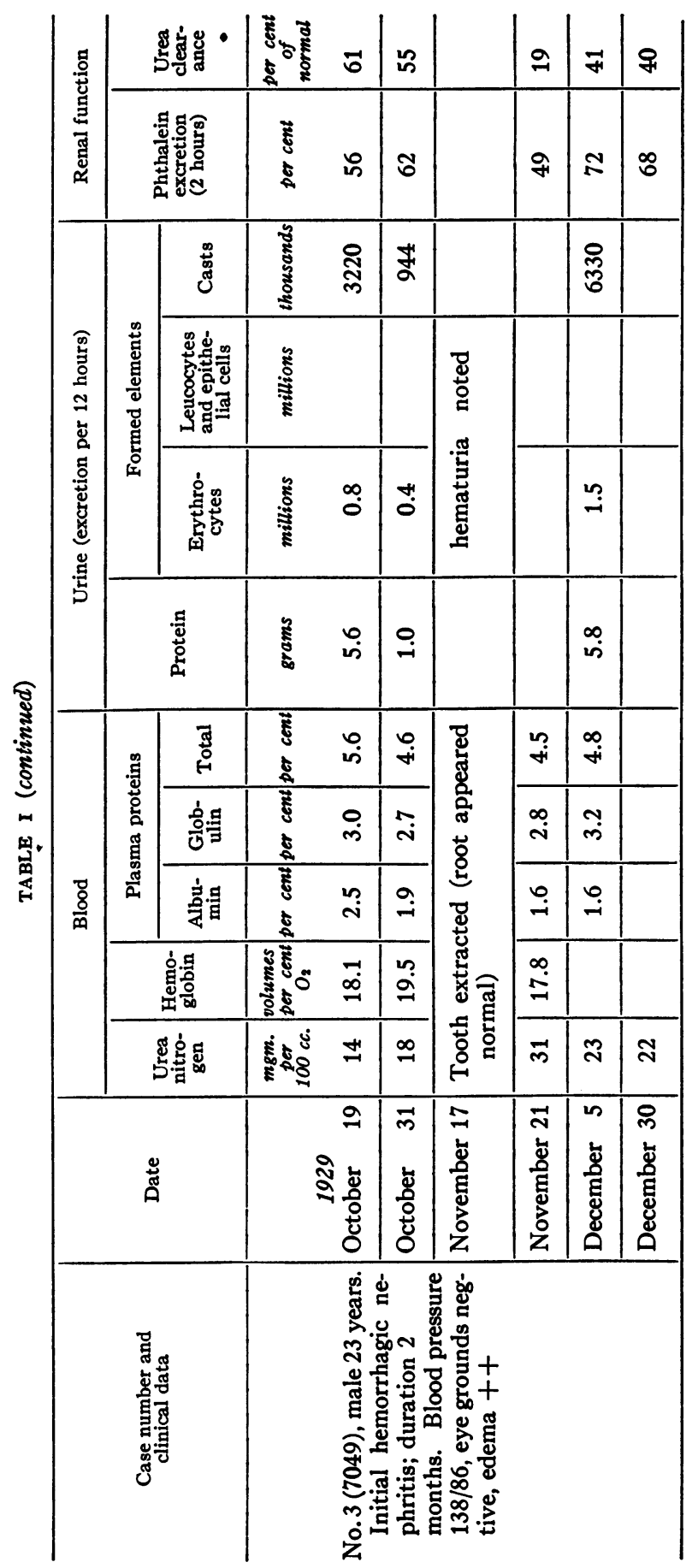


IRVINE H. PAGE AND ALF ALVING

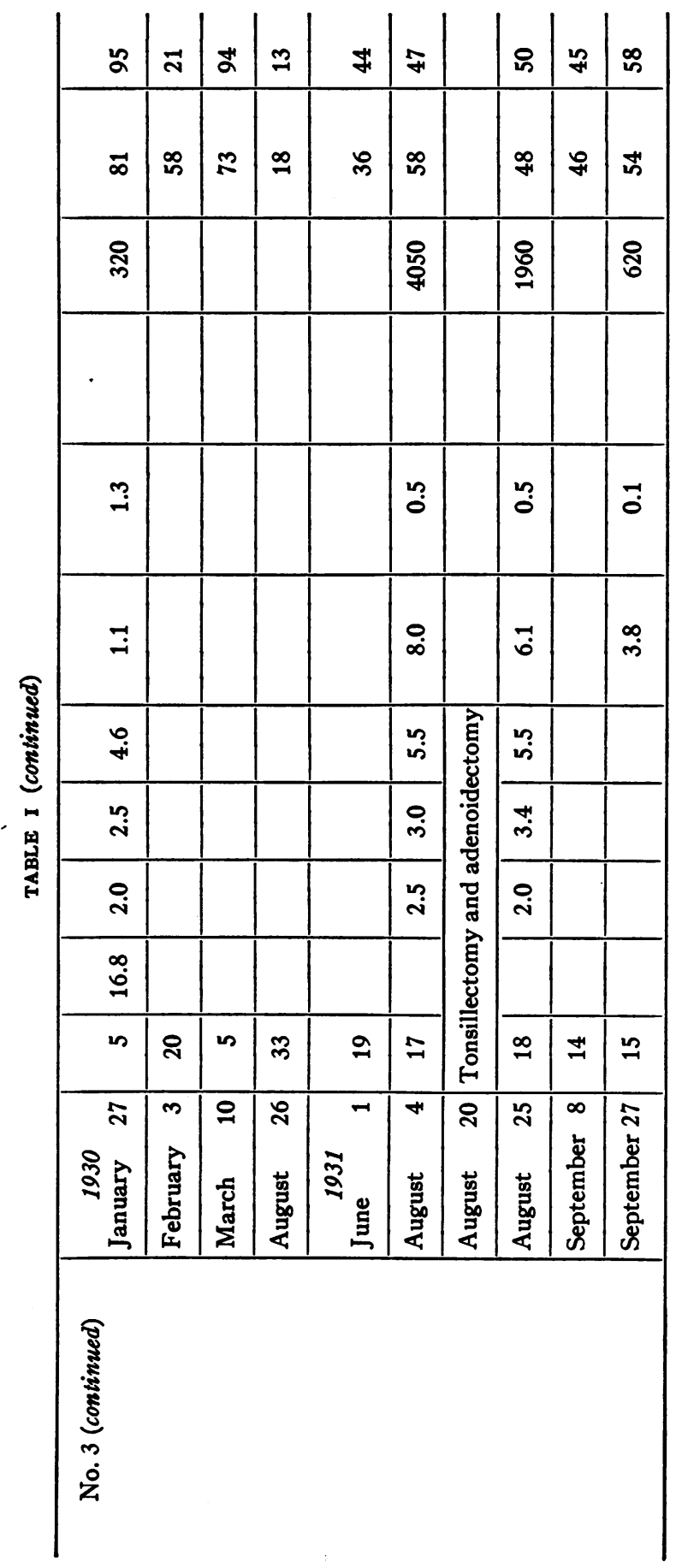




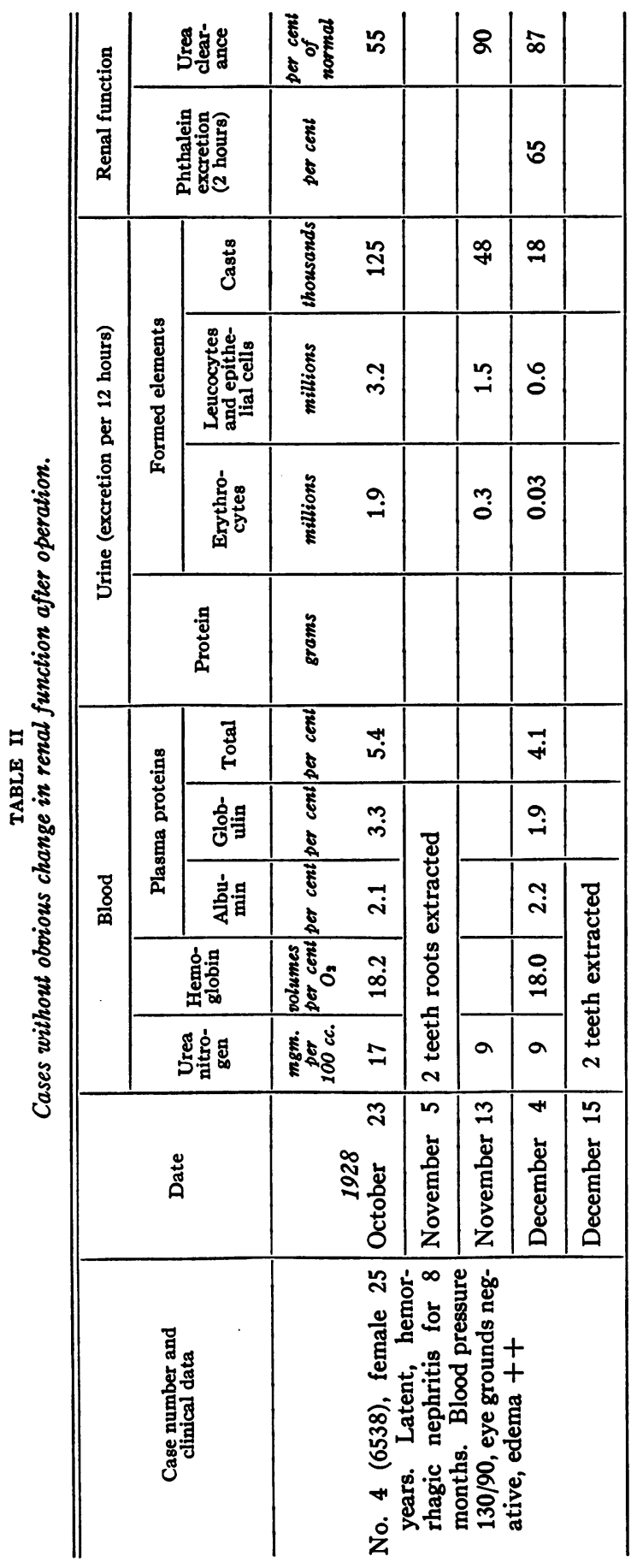


IRVINE H. PAGE AND ALF ALVING

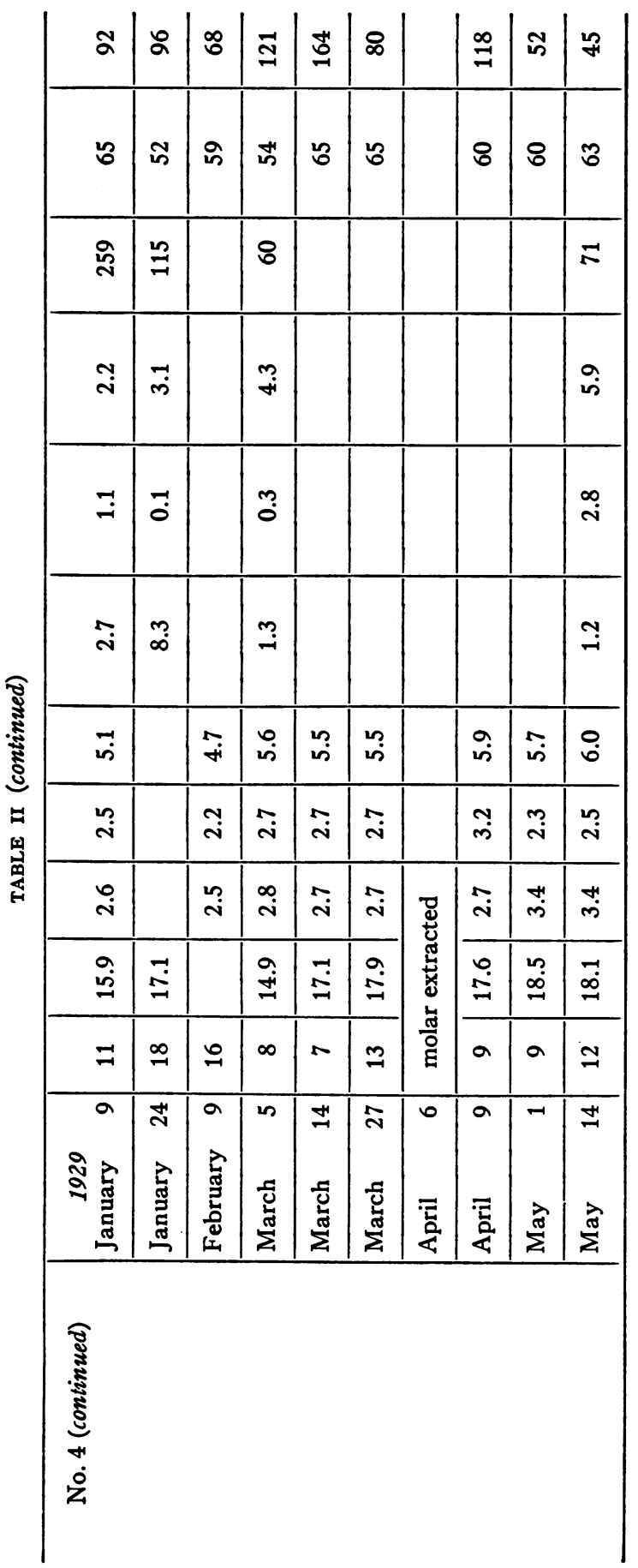




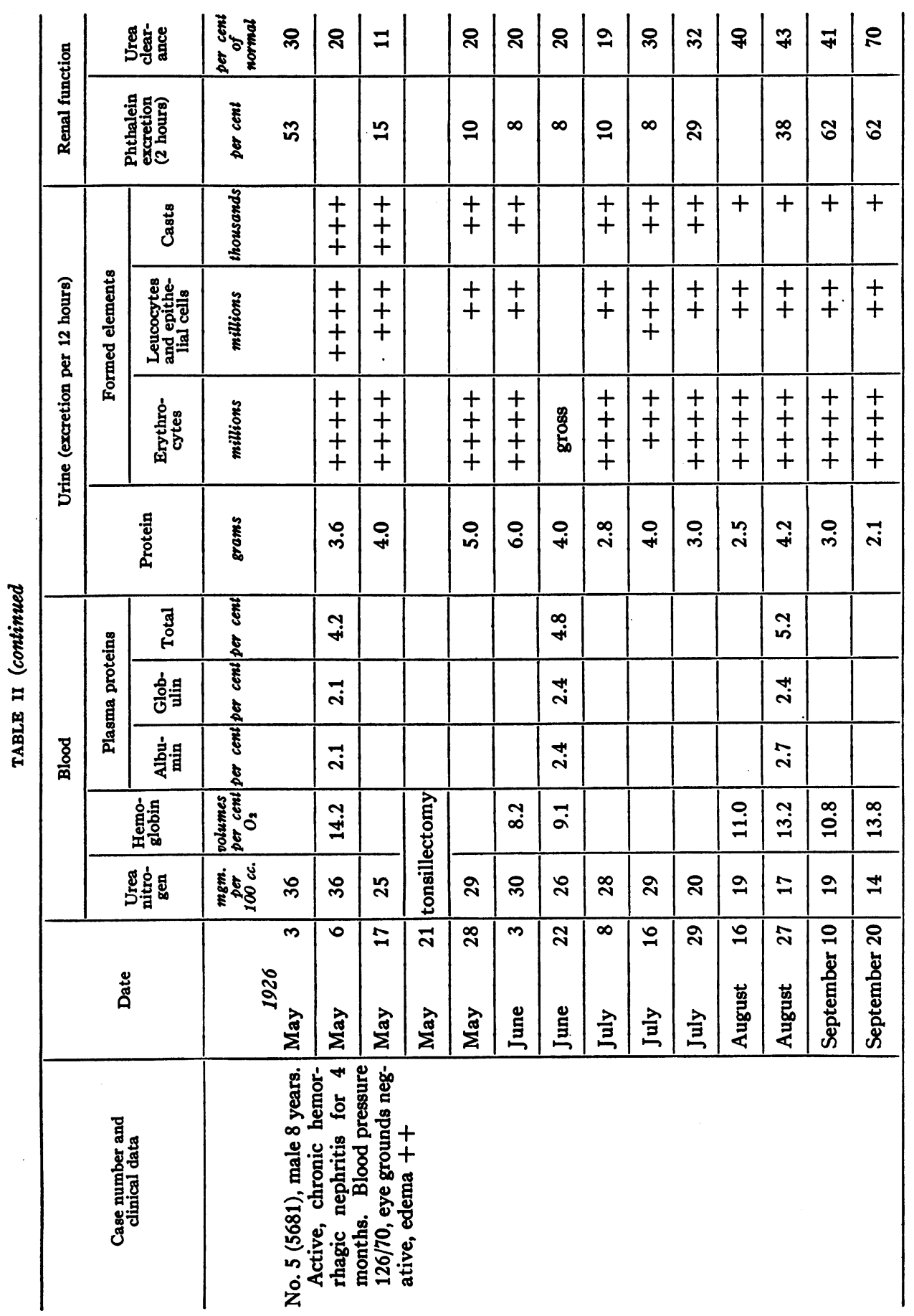


IRVINE H. PAGE AND ALF ALVING

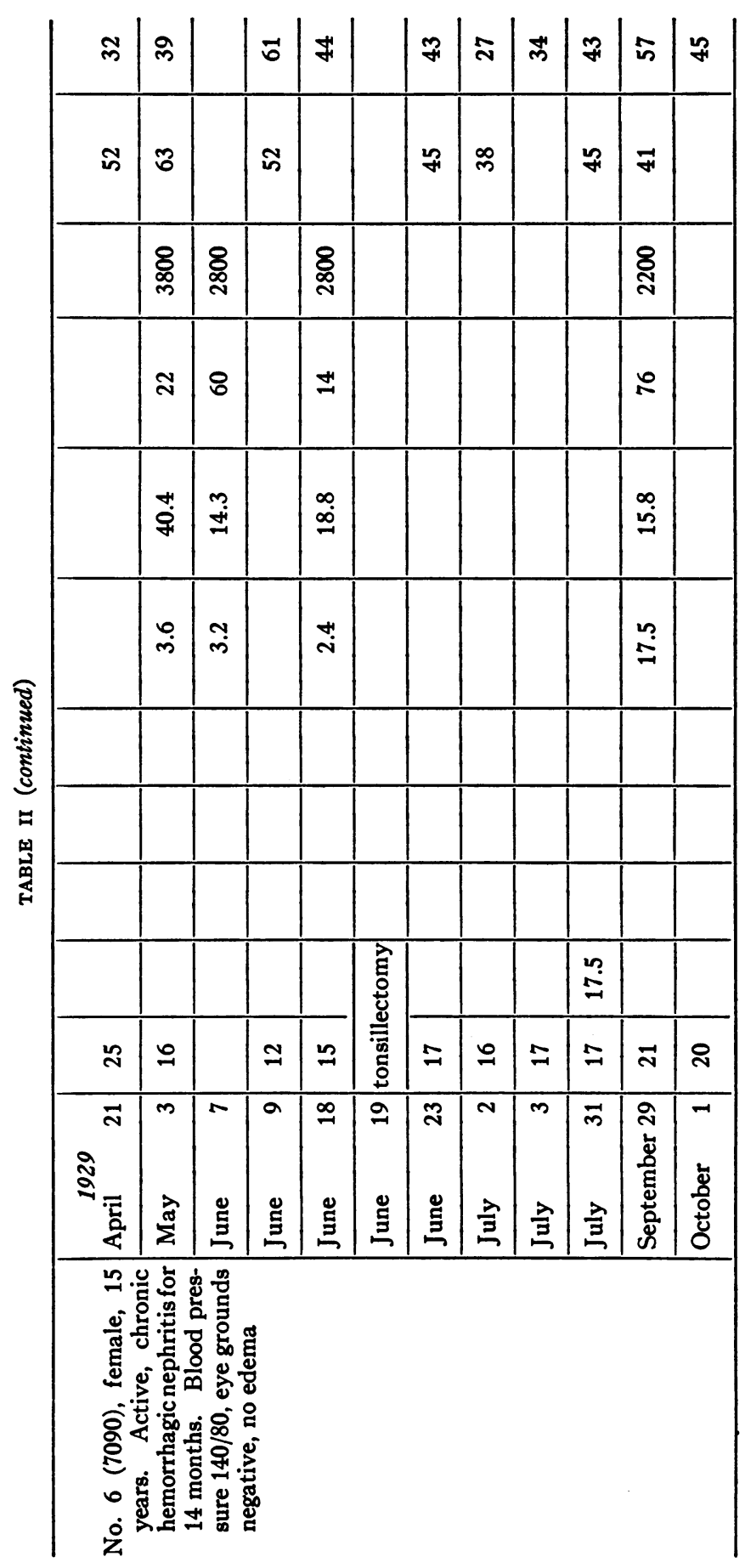




\begin{tabular}{|c|c|c|c|c|c|c|c|c|c|c|c|c|}
\hline \multirow{2}{*}{ 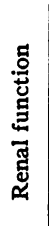 } & \multicolumn{2}{|c|}{ 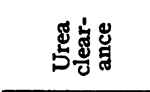 } & 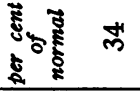 & 吕 & $\vec{m}$ & $\stackrel{\infty}{\infty}$ & & "ే & $\vec{F}$ & $\underset{ల}{\infty}$ & बे & 尺े \\
\hline & \multicolumn{2}{|c|}{ 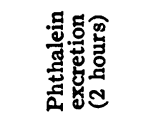 } & $\begin{array}{l}\vec{E} \\
\text { E } \\
\text { \& }\end{array}$ & & & & & & & & & \\
\hline \multirow{4}{*}{ 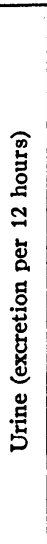 } & \multirow{3}{*}{ 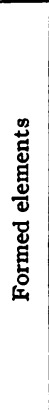 } & 志 & 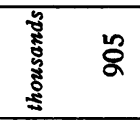 & & & & & & & 苍 & 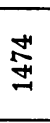 & \\
\hline & & 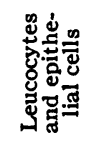 & 苋 & & & & & & & ஜ̊. & $\stackrel{m}{\not}$ & \\
\hline & & 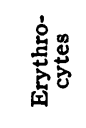 & 气气 & & & & & & & $\stackrel{\infty}{\circ}$ & $\stackrel{\infty}{0}$ & \\
\hline & \multicolumn{2}{|c|}{ 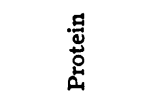 } & 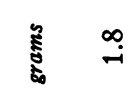 & & & & & & & $\stackrel{\sim}{\sim}$ & $\stackrel{0}{-}$ & \\
\hline \multirow{5}{*}{$\frac{\square}{0}$} & \multirow{3}{*}{ 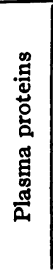 } & 丞 & हू & & $\stackrel{+}{+}$ & & & $\stackrel{9}{+}$ & & & & \\
\hline & & 웡몽 & है & & $\hat{i}$ & & & $\vec{i}$ & & & & \\
\hline & & 产晁 & हु & & 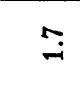 & & & $\stackrel{\infty}{i}$ & & & & \\
\hline & \multicolumn{2}{|c|}{ 递告 } & ") & & $\stackrel{0}{0}$ & & \multirow{2}{*}{ 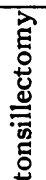 } & & & $\ddot{n}$ & & \\
\hline & \multicolumn{2}{|c|}{ 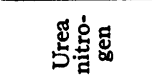 } & 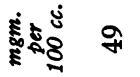 & $\stackrel{\infty}{+}$ & $\stackrel{\infty}{\sim}$ & 요 & & ర్ల & $\stackrel{\infty}{\sim}$ & શิ & స్ & $\tilde{\sim}$ \\
\hline & \multicolumn{2}{|c|}{ ڤึّ } & 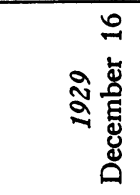 & 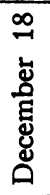 & 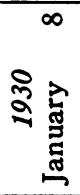 & 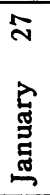 & 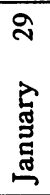 & 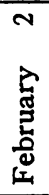 & $\begin{array}{l}\exists \\
\overrightarrow{0} \\
\frac{3}{2} \\
\frac{0}{0}\end{array}$ & 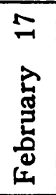 & $\begin{array}{l}= \\
\text { I } \\
\text { 苞 }\end{array}$ & $\begin{array}{l}\text { d } \\
\text { 范 } \\
\sum^{\pi}\end{array}$ \\
\hline & \multicolumn{2}{|c|}{ 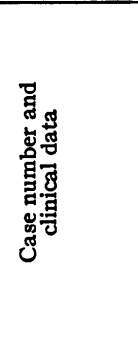 } & \multicolumn{4}{|c|}{ 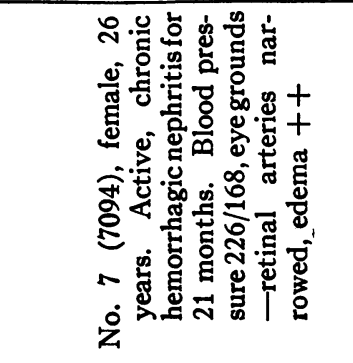 } & & & & & & \\
\hline
\end{tabular}




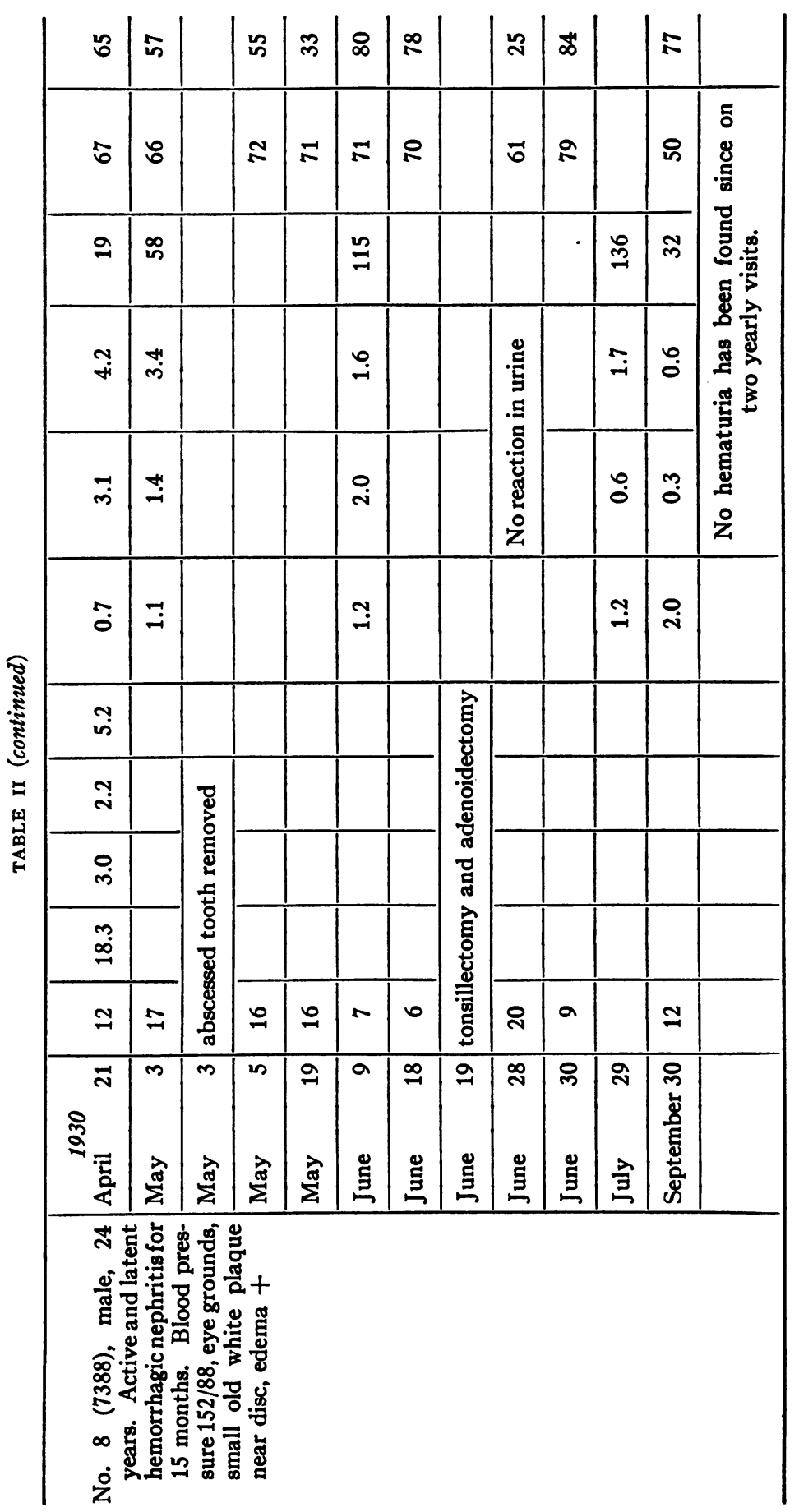


In this case in spite of difficulty of interpretation due to the rapidly progressive and virulent qualities of the disease it would appear that operation speeded the course.

The second patient (No. 2) suffered from hemorrhagic Bright's disease in the terminal stage. The disease was progressive and caused a rapid loss of kidney function. The patient was continually beset with complications such as abscesses, sties, conjunctivitis, edema and tonsillitis. His temperature was slightly elevated, his appetite poor, and he had vomited a number of times on previous days. In spite of the adverse condition of the patient, the tonsils were considered so badly infected that their removal was indicated. Following operation his temperature rose to $101.6^{\circ}$, nausea persisted. The ninth day after operation the clearance had fallen to 10 per cent of normal. The patient recovered satisfactorily from the operation but directly following the tonsillectomy the patient seemed to be on the verge of uremia.

The third patient (No. 3) had Bright's disease with a marked nephrotic tendency. On November 17, one tooth was extracted which proved to be normal. There was no fever directly following the operation, although there had been fever for the three previous days. However, for the first time since admission red blood cells in pathological quantities were found in the urine sediment. On November 19, the tooth socket seemed in good condition but the tonsils were swollen and pharyngitis was present. There was a moderate decrease in the urine output, but this decrease had begun three days before the extraction. A marked fall in the urea clearance occurred. This would be a rather convincing indication of the effect of the operation on the ability of the kidney to excrete urea had not a very similar episode occurred a month later (January 6 to January 15) when no operative procedure was employed. Oliguria, hematuria and general prostration were evident. After recovery from this incident the clearance rose sharply to 95 per cent on January 27 , but fell again to 21 per cent on February 3. From this period his clearance fluctuated markedly and usually without any apparent reason. He seemed peculiarly susceptible to upper respiratory infections. On August 20, of the following year, tonsillectomy and adenoidectomy were performed without effect on the kidney function and the excretion of red blood cells. The patient recovered rapidly from the operation.

\section{DISCUSSION}

Except for the three cases which are discussed in detail above, the operations on 31 nephritic patients caused no significant fall or rise in the kidney function as measured either by the urea clearance or phenolsulphonphthalein excretion.

Of the 28 cases who showed no significant renal effects after operation, it has not seemed necessary to report complete data. The observations in Table II covering five of these cases, suffice to show the nature of the results.

The plasma proteins do not appear changed to any evident degree by operation, whereas hemoglobin shows a tendency to fall slightly. Whether the latter is due to the loss of blood at the operation, or is to be credited to the natural progress of the disease is not certain. Urinary protein is not significantly altered. In some cases an increase in hematuria has been noted following operation, in some no change, and in still 
others a reduction is found. Casts are equally erratic in their appearance. In all respects the effects appear to have been transient, and to have disappeared from a few days to a fortnight after the operation.

The data on the 31 cases discussed above do not cover periods sufficiently long after operation to bear on the effect of the operations on the ultimate course of the disease. However, the charts published in a previous monograph from this hospital (8) do appear to provide some basis for an opinion on this question. Of the $\mathbf{5 0}$ cases of acute and chronic hemorrhagic renal disease there reported, seventeen (Numbers 1, 3, 4, $7,10,12,13,17,18,25,26,27,29,31,33,36,48$ ) were subjected to operation, usually tonsillectomy, and were observed for months or years thereafter. Comparison of these charts with those of similar cases that were not subject to operation gives, we believe, a definite impression that the tonsillectomies were without effect, either favorable or unfavorable, on the course of the disease. The natural variability of the disease makes it impossible to state dogmatically this conclusion. We believe, however, that anyone who will compare the series of charts referred to with charts of unoperated cases in the same monograph will have difficulty in finding evidence for any effect of the operation on the course of the renal disease.

Experience with these and other cases has led to the conclusion in this clinic that in nephritic patients removal of tonsils, adenoids, and teeth are operations to be undertaken or not from the standpoint of the general hygiene of the patient, and without expectation that his renal disease will be benefited. On the other hand, unless the general condition is bad, it does not seem necessary to refuse an operation because of a somewhat diminished renal function. If the disease has been very active and the general condition poor, there may be danger of bringing on uremia in the days following the operation. But such danger seems to be remote, in subjects with blood urea clearances above 20 per cent of normal, if the general condition is not depressed by factors other than renal retention.

\section{CONCLUSIONS}

The operations of tonsillectomy, adenoidectomy and tooth extraction have usually had no effect on kidney function as measured by the urea clearance or the phthalein excretion. In 3 out of 31 cases, however, renal function was depressed in the days immediately after operation, and in one case, already terminal, uremic symptoms were brought on.

2. Red blood cells and casts in the urine were frequently increased for some days after operation. Such increase usually occurred without any fall in renal function.

3. Plasma protein content and urinary protein excretion were not affected by these operations. The hemoglobin content of the blood was in some cases somewhat decreased, perhaps as the result of loss of blood during the operation. 
4. The results, together with more prolonged observations presented in a previous report (8), lead to the conclusions that removal of tonsils, adenoids, or teeth usually has no effect, favorable or unfavorable, on the progress of renal disease, but that when the general hygiene of a renal patient demands such an operation it is not necessary to refuse it, unless the renal disease is in the terminal stage (urea clearance consistently below 20 per cent of normal), or the general condition of the patient is unfavorable.

\section{BIBLIOGRAPHY}

1. Addis, T., J. Am. Med. Assoc., 1925, lxxxv, 163. A clinical classification of Bright's disease.

2. Möller, E., McIntosh, J. F., and Van Slyke, D. D., J. Clin. Invest., 1928, vi, 485. Studies of urea excretion. IV. Relationship between urine volume and rate of urea excretion by patients with Bright's disease.

3. Moore, N. S., and Van Slyke, D. D., J. Clin. Invest., 1930, viii, 337. The relationships between plasma specific gravity, plasma protein content and edema in nephritis.

4. Peters, J. P. and Van Slyke, D. D., Quantitative Clinical Chemistry. Interpretations, Volume I, Williams and Wilkins Co., Baltimore, 1931, p. 544 .

5. Shevky, M. C. and Stafford, D. D., Arch. Int. Med., 1923, xxxii, 222. A clinical method for the estimation of protein in urine and other body fluids.

6. Van Slyke, D. D., Alving, A., and Rose, W. R., (unpublished observations).

7. Van Slyke, D. D., McIntosh, J. F., Möller, E., Hannon, R. R., and Johnston, C., J. Clin. Invest., 1930, viii, 357. Studies of urea excretion. VI. Comparison of the blood urea clearance with certain other measures of renal function.

8. Van Slyke, D. D., Stillman, E., Möller, E., Ehrich, E., McIntosh, J. F., Leiter, L., MacKay, E. M., Hannon, R. R., Moore, N. S., and Johnston, C., Medicine, 1930, ix, 257. Observations on the courses of different types of Bright's disease and on the resultant changes in renal anatomy. 